\title{
TERRITÓRIO, CLASSE E MOVIMENTOS SOCIAIS NO CAMPO
}

\section{Territory, Class and Social Movements in the Field}

Prof. Dr. João E. Fabrini

Pós-Graduação em Geografia da Universidade Estadual do Oeste do Paraná Rua Pernambuco, 1777, Centro, CEP: 85960-000 - Marechal Candido Rondon (PR), Brasil

Tel/Fax: (+55 45) 32847870 / 32847879 - fabrini2@ibest.com.br

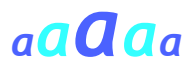

\begin{abstract}
Resumo
Existe forte conexão entre território e movimentos sociais, pois ambas as categorias estão relacionadas à transferência das decisões de cúpulas estatais, empresariais e partidárias para a base da sociedade civil organizada. A transferência de poder para a base pode se comunicar com a doutrina liberal, pois os próprios sujeitos, investidos de poder e controle sobre o espaço, se encarregam de resolver seus problemas, forjando uma desobrigação estatal. Entretanto, as decisões na base e a dimensão territorial, concebida numa perspectiva classista, servem para fortalecer os movimentos sociais, lutas e resistências camponesas contra a hegemonia capitalista. Assim, dependendo da ótica da abordagem, o território pode reforçar ou negar a ordem mercadológica.
\end{abstract}

Palavras-chave: Território; movimentos sociais; resistência camponesa.

\begin{abstract}
There is strong connection between territory and social movements, since both categories are related to the transfer of the decisions of state summits, business and party for the foundation of civil society organizations. The transfer of power to the base can communicate with the liberal doctrine, because the subjects themselves invested with power and control over space, in charge of solving their problems, forging a release state. However, decisions on the base and the territorial dimension, designed a class perspective, serve to strengthen social movements, peasant struggles and resistance against capitalist hegemony. Thus, depending on the perspective of the approach, the territory can enhance or negate the marketing order.
\end{abstract}

Key words: Territory, social movements, peasant resistance.

\section{Resumen}

Existe fuerte conexión entre territorio y movimientos sociales, pues ambas categorías están relacionadas a la transferencia de las decisiones de cúpulas estatales, empresariales y partidarias para la base de la sociedad civil organizada. La transferencia de poder para la base puede comunicarse con la doctrina liberal, pues los propios sujetos, investidos de poder y control sobre el espacio, se encargan de resolver sus problemas. Entre tanto, las decisiones en la base y la dimensión territorial, concebida en una perspectiva clasista, sirven para fortalecer los movimientos sociales, luchas y resistencias campesinas contra la hegemonía capitalista. Así, dependiendo de la óptica de abordaje, el territorio puede reforzar o negar el orden mercadológica.

Palabras clave: Territorio; movimientos sociales; resistencia campesina.

\section{$a \propto \boldsymbol{Q}_{a} a$}




\section{INTRODUÇÃO}

O espaço agrário brasileiro está em constante transformação e a cada momento são acrescentados novos conteúdos que pedem interpretação à geografia e à ciência. Nesse contexto de transformações, o território emerge como categoria e dimensão basilar da realidade espacial. A concepção hegemônica de território é a de que ele se constitui num espaço sob controle e domínio de um grupo social, estado, corporação, indivíduo, dentre outros.

Existe forte conexão entre movimentos sociais e território, pois ambas as categorias estão relacionadas à transferência das decisões de cúpulas estatais, empresariais e partidárias para a base da sociedade civil organizada. Portanto, território e movimentos sociais estão à contramão de decisões centralizadas e tratam-se de uma ordenação social construída de baixo para cima.

A transferência de poder para a sociedade civil organizada pode se comunicar com o ideário liberal, pois os próprios sujeitos, investidos de poder e controle sobre o espaço, se encarregam de resolver seus problemas, forjando uma desobrigação estatal. Dessa forma, a dimensão territorial pode se vincular a um antiestatismo em nome do poder à sociedade civil organizada e, por isso, empresários, órgão multilaterais, governos e intelectuais, dentre outros, aprovam tal dimensão. Acrescenta-se ainda que o território pode potencializar a capacidade produtiva oferecendo vantagens competitivas para produção de mercadorias e desenvolvimento local.

Entretanto, o território, visualizado numa perspectiva classista, pode servir para negar estruturas de dominação e potencializar a capacidade de resistência da agricultura camponesa nos movimentos sociais. Nessa concepção de território, o conflito de diferentes projetos está colocado no centro do processo social, pois implica numa disputa de poder e controle do espaço pelas diferentes classes.

\section{CONCEPÇÃO LIBERAL E CLASSISTA DE TERRITÓRIO}

Existem diferentes interpretações de território feitas a partir do enfoque econômico, cultural, político, simbólico-imaterial etc. Saquet (2007) apresenta diversas abordagens e concepções de território.

A interpretação hegemônica de território foi construída por diversos autores a partir do pensamento de Raffestin (1993). O território é visto como emanação de poder derivada do Estado (território nação) ou grupos sociais capazes de exercer determinado controle, domínio, comando e autoridade sobre o espaço .

Segundo Haesbaert (2004), a sociedade não pode viver sem território. Para o autor, a desterritorialização se constitui num mito porque quando o sujeito é desterritorializado, ele se territorializa em outro espaço.

O mito da desterritorialização é o mito dos que imaginam que o homem pode viver sem território, que a sociedade pode existir sem territorialidade, como se o movimento de destruição do território não fosse sempre, de algum modo, sua reconstrução em novas bases. Território, visto aqui numa perspectiva geográfica, intrinsecamente integradora, vê a territorialização como o processo de domínio (políticoeconômico) e/ou de apropriação (simbólico-cultural) do espaço pelos grupos humanos (HAESBAERT, 2004, p. 16).

Observa-se que embora a sociedade não possa existir sem territorialidade, pode haver uma territorialização precária dos sujeitos. Neste caso, o sujeito ou grupo social possui precário domínio sobre o espaço. Exemplo de territorialização precária são os brasiguaios, pois estão em constante mobilidade na busca do território na fronteira do Brasil com o Paraguai.

A delimitação ou jurisdição de poder implícita no território possui uma escala que pode ser macro, como uma nação ou conjunto de nações, ou micro, como uma propriedade rural, por exemplo. O poder institucionalizado expresso no Estado, principalmente, garante o domínio do espaço, configurando o território de uma nação. 
Contudo, o território pode se constituir à margem da institucionalidade, quando a sociedade civil organizada assume poder sobre o espaço, como num acampamento de sem-terra, por exemplo, em que o controle pertence aos sujeitos organizados no movimento social. Embora o controle do espaço de um acampamento não seja total, é ilustrativa a declaração de um sem-terra acampado: "aqui no acampamento nem a polícia entra sem a ordem do grupo de segurança. Só entra quando tem despejo, na força mesmo" (informação verbal, 2009). Assim, a formação do território está sujeita às forças sociais que são protagonistas no processo de sua formação.

Existe uma interpretação de território como potencializador do empreendedorismo e da organização produtiva de base local para obtenção de vantagens competitivas mercadológicas. Nessa perspectiva, o território se constitui num trunfo para expansão da produção de mercadorias que se nutre e deriva da força local.

O desenvolvimento local expressa essa força do território para produção de mercadorias. Por isso, nessa perspectiva liberal, o enfoque territorial se casa com a compreensão de corporações capitalistas, governos e partidos neoliberais, órgãos multilaterais, intelectuais e até movimentos sociais.

Na América Latina, as políticas de desenvolvimento com base no enfoque territorial vêm sendo adotadas por recomendação das agências multilaterais e por iniciativa de governos nacionais. Não obstante as recomendações, essas estratégias vêm encontrando respaldo nos movimentos sociais localistas, que reivindicam maior participação na formulação de gestão das políticas publicas (ORTEGA, 2008, p. 13).

O contexto local se ergue como esfera privilegiada no processo de desenvolvimento e é colocado como elemento fundante nas relações. A partir de diferentes imbricações é possível chegar ao desenvolvimento territorial rural (DTR), "irmão gêmeo" do desenvolvimento local. A pequena agricultura, por exemplo, seria portadora de desenvolvimento, pois oxigena a produção de mercadorias na escala local, regional e nacional, permitindo a formação de uma trama virtuosa para o desenvolvimento de trocas comercias.

O que os autores chamam de "enfoque de DTR (desenvolvimento territorial rural)" é a visão de um duplo processo de transformação - produtiva e institucional - de espaço bem determinados. A transformação produtiva deve articular a economia desses territórios e mercados dinâmicos, de forma competitiva e sustentável. A transformação institucional deve facilitar a interação e a construção de confiança entre os atores locais, não somente entre si, mas também entre eles e os atores externos relevantes com o propósito de ampliar as oportunidades participativas da população no processo e em seus benefícios (VEIGA, 2005, p. 85).

Assim, o DTR e o desenvolvimento local expressam da força do território para a produção de mercadorias e oportunidades em mercados dinâmicos, permitindo aos pequenos negócios se inserirem em diferentes escalas e cadeias produtivas. $\mathrm{O}$ caminho para obtenção de vantagens à pequena agricultura é operar como um "agronegócio familiar". A diferença entre a produção familiar e a capitalista seria apenas de escala e o lugar social desse "agronegócio familiar" estaria garantido pela eficiência produtiva derivada da força local do território.

Assim, o desenvolvimento local e a operacionalização da pequena agricultura como um "agronegócio familiar" visam fazer dos camponeses - e sua tradicional insurgência a esquemas opressores - sujeitos submissos, inofensivos e dóceis agentes da ordem mercadológica, construída a partir da dimensão local.

A força local do território, considerada base para potencialização de trocas competitivas e o desenvolvimento, está relacionada ao "capital social". O capital social diz respeito à proximidade social (cooperação, parceria, confiança, ajuda mútua, coalizão, coesão e reciprocidades diversas) dos sujeitos para obtenção de vantagens competitivas. O local permite uma proximidade social que se traduz em empoderamento de organizações sociais, grupos, empresas, instituições públicas etc. 
Muito mais importantes que vantagens comparativas decorrentes de atributos naturais ou de localização são as vantagens competitivas construídas pelo fenômeno da proximidade social, o que permite uma coordenação entre os atores capaz de valorizar o conjunto de ambiente em que atuam e, portanto, de convertê-los em base para outros empreendimentos inovadores (VEIGA, 2005, p. 83).

Concebido dessa forma, o capital social dos territórios implica na cooperação e parcerias, e não confrontos, entre os diversos "atores" sociais. Trata-se de uma posição, ou proposição, não-crítica às estruturas sociais com a cooperação das diversas frações da sociedade representadas pelas empresas, governos, organizações, movimentos sociais etc. Nesse sentido, a sociedade civil organizada deve ser colaboradora, parceira, e não opositora combatente de empresas, governos, corporações, cooperativas etc. A proximidade social expressa no capital social escamoteia a dimensão de classes implícita no território e se desdobraria numa "soma" em que todos ganham.

As coalizões entre empresas e pequenos agricultores, inclusive, seriam capazes de realizar a preservação de ecossistemas básicos, fonte fundamental de geração de ganhos econômicos. O capital social permitiria a formação dos clusters no território, ou seja, agrupamentos locais de empresas do mesmo ramo para obtenção de vantagens competitivas por meio da cooperação entre elas, e não da rivalidade. Assim, os movimentos sociais combativos às empresas do agronegócio, por exemplo, estariam à contramão do desenvolvimento territorial.

Segundo Abramovay (1998), a partir do território, os projetos de desenvolvimento abrangem os diversos setores profissionais e atividades econômicas de um determinado espaço. Os agricultores familiares, porém, por não estarem dotados de capital social e prerrogativas necessárias ao desenvolvimento, como educação, crédito e informação, não são vistos como protagonistas no pacto territorial.

Projetos de desenvolvimento terão tanto mais chances de sucesso quanto mais forem capazes de extrapolar um único setor profissional. O desenvolvimento territorial apóia-se, antes de tudo, na formação de uma rede de atores trabalhando para valorização dos atributos de uma certa região. Exatamente por não estarem dotados das prerrogativas necessárias ao desenvolvimento (da educação, da formação, do crédito, da informação) os agricultores não são encarados pelo restante da sociedade local como potenciais protagonistas de um pacto territorial (ABRAMOVAY, 1998, p. 8).

Nessa interpretação ainda, o território possui uma perspectiva multidimensional e integradora dos diversos segmentos sociais. $\mathrm{O}$ território se constituiria numa síntese espacial que agrega diferentes sujeitos em uma coesão construída a partir do pertencimento a um determinado espaço. O sujeito se vê incluído e partícipe a partir do espaço, e não da classe ou categoria social a que pertence.

Os "territórios rurais" defendidos pelo Ministério do Desenvolvimento Agrário (MDA) são exemplares dessa perspectiva integradora, pois agregam sujeitos diversos numa coesão forjada a partir do espaço, e não das atividades econômicas e posição social. Os "territórios rurais" pressupõem a unidade de classes e atividades, inclusive aquelas não-agrícolas, pois o rural não seria mais sinônimo de agricultura, tal como destacou Silva (1997) ao tratar do Novo Rural. Assim, seria necessária uma categoria conceitual capaz de apreender a complexidade da realidade agrária, nesse caso, o território.

O conteúdo de síntese integradora do território deverá pautar também a formulação de políticas públicas. Tais políticas devem estimular parcerias múltiplas de diversos setores e sujeitos sociais na esfera municipal, estadual e federal para a obtenção de vantagens e oportunidades de negócio, principalmente. A elaboração e implantação de políticas públicas a partir do território, inclusive, visam superar a dicotomia urbano-rural, integrando tais espaços.

Portanto, a heterogeneidade de territórios leva à necessidade de se formularem políticas com objetivos múltiplos e integrais, que atendam as principais demandas dos atores sociais, pois somente dessa forma 
será possível a formação de alianças e parcerias, que concretizem o capital social, em benefício de todos. Não devem restar excluídos nem perdedores por deficiência na formulação de políticas públicas (MDA, 2003, p. 27).

Os Conselhos Municipais (CM), que tomaram força a partir da promulgação da Constituição de 1988, seriam uma importante estratégia municipal de desenvolvimento construída a partir do território. Os Conselhos Municipais de Desenvolvimento Rural (CMDR), por exemplo, indicam poder decisório transferido para municípios e "atores" sociais locais com possibilidade de parcerias entre os diversos setores sociais na esfera municipal.

Os consórcios municipais que tomaram impulso a partir de ações do governo Lula também devem pautar políticas públicas numa perspectiva integradora e multidimensional do território. Os Consórcios Intermunicipais de Segurança Alimentar e Desenvolvimento Local (Consad) são exemplares de integração dos diferentes sujeitos e transferência das decisões para a esfera local. Tais consórcios buscam a união de lideranças políticas locais, como prefeitos(as), entidades empresariais e sua representação, trabalhadores, camponeses e diversas organizações civis na solução dos problemas relativos à segurança alimentar e desenvolvimento local.

É exatamente com este intuito que as recentes políticas de desenvolvimento territorial vêm sendo formuladas, visando a constituição de arranjos sócio-produtivos intermunicipais, que possam estabelecer uma articulação que propicie maiores possibilidades de êxito numa escala organizacional superior àquela dos arranjos municipais. Para tanto, busca-se articular politicamente os municípios para criar condições para que seja firmado um pacto intermunicipal com a finalidade de obter o desenvolvimento territorial (ORTEGA, 2008, p. 88).

Embora guardadas as diferenças, o desenvolvimento erguido a partir das forças integradoras do território esteve presente tanto nas políticas de corte "liberal-desenvolvimentista" do governo Lula, quanto no período anterior de neoliberalismo aberto do governo FHC, em que se dispensava a participação do Estado como indutor do desenvolvimento.

Para além das políticas públicas, tomam corpo também na perspectiva territorial as ações voluntárias em redes de desenvolvimento local, quando a população protagoniza ações comunitárias para melhorar o ambiente em que vive. Exemplar, nessa perspectiva, é o Projeto da Rede de Desenvolvimento Local no Paraná, estimulado pela Federação das Indústrias do Estado do Paraná (Fiep) e o Serviço Social da Indústria (Sesi) para formar e mobilizar agentes comunitários no sentido de pensar, planejar e executar ações voluntárias que possam acelerar o desenvolvimento das localidades. (FRANCO e CARREIRA, 2010, p. 3).

Entretanto, a perspectiva de síntese integradora e multidimensional do território é passível de crítica, pois se desvia das coalizões dos sujeitos a partir do trabalho ou classe social. Nessa compreensão, os camponeses, por exemplo, são diluídos em meio a outros sujeitos, pois agora, a partir do território, não há sentido em diferenciar camponeses de não-camponeses, porque ambos estão inseridos no mesmo espaço. Essa síntese integradora, que junta no mesmo espaço camponeses e não-camponeses, pode comprometer inclusive a concepção de "territórios rurais", pois neles estão inseridas diferentes camadas urbanas da sociedade.

A unidade dos sujeitos a partir da classe social fica escamoteada em nome de uma suposta unidade de camponeses, movimentos sociais, empresas, governos e trabalhadores, forjada a partir do território. Essa compreensão de unidade secundariza o processo de coesão a partir de categorias e classes sociais, o que se desdobra numa despolitização e desideologização do território.

Além da limitação integradora e multidimensional do território, outra deve ser acrescentada, sobretudo aquela relativa à dimensão local enquanto uma esfera de decisão. O local e as decisões de base, pressupostos do território, nem sempre são sinônimos de participação democrática e igualdade. Muitas vezes a base local serve para legitimar decisões tomadas por cúpulas estatais e empresariais. 
A proposta de "orçamento participativo" implantada em algumas prefeituras administradas pelo Partido dos Trabalhadores (PT) é importante exemplo de transferência de decisões orçamentárias para as bases. No entanto, no caso de territórios deprimidos , não apresenta os resultados esperados, pois o poder público municipal, por meio de cooptação e manobras diversas, impõe muitas vezes à comunidade suas próprias demandas, metas e propostas orçamentárias. Dessa forma, uma força de cima se impõe sobre o território, e a base (bairro, comunidade, distrito, linha) acaba legitimando tais imposições.

Assim, a esfera local pode abrir possibilidade para uma espécie de "prefeiturização" das relações sociais, e administradores públicos, inclusive do PT, agem muitas vezes como "coronéis locais", utilizando-se de vínculos pessoais de controle e domínio.

Segundo Brandão (2007), o consenso em torno dos localismos acabou gerando um pensamento único em torno de ações políticas e arranjos sócio-produtivos endogenistas de desenvolvimento, recebendo amplo apoio e respaldo de diversos segmentos sociais. O apoio amplo ergue-se a partir da concepção integradora e desclassificada de território, pois poderá, como destacado anteriormente, congregar em torno de objetivos comuns empresário, trabalhadores, camponeses, poder público etc.

Entretanto, é necessária e possível uma interpretação de território que considere a perspectiva classista, expressa nas contradições dos interesses sociais que dão as diretrizes na formação do território. No sentido de compreender o território à luz do contexto contraditório das relações sociais de produção é necessário recuperar a interpretação de Oliveira (2007). O autor coloca o contexto de classe no centro das interpretações, pois são as relações sociais de produção que "dão as cartas" na configuração do território.

O território é assim, produto concreto da luta de classes travada pela sociedade no processo de produção de sua existência. Sociedade capitalista que está assentada em três classes fundamentais: proletariado, burguesia e proprietários de terra. Dessa forma, são as relações sociais de produção e o processo contínuo/contraditório de desenvolvimento das forças produtivas que dão a configuração histórica específica ao território. Logo o território não é um prius ou um a priori, mas a contínua luta da sociedade pela socialização igualmente contínua da natureza. [...] É esta lógica contraditória que constrói/destrói formações territoriais em diferentes partes do mundo ou faz com que frações de uma mesma formação territorial conheçam processos desiguais de valorização, produção e reprodução do capital, conformando as regiões (OLIVEIRA, 2007, p. 3, grifos do autor).

Acrescenta-se ainda que o território formado a partir das contradições sociais se constitui numa força capaz de potencializar a resistência camponesa à ordem dominante, imposição de oligarquias, opressão e poder das forças mercadológicas. Nesse sentido, o território pode ser interpretado como resistência e possibilidade de ampliação das lutas contra esquemas de dominação e subordinação engendrados na sociedade capitalista.

Alguns movimentos sociais, como o Movimento dos Pequenos Agricultores (MPA) e a Via Campesina, se utilizam do enfoque territorial na construção de propostas emancipatórias. Esse é o caso do Sistema Camponês de Produção (SCP), de fabricação de agrocombustível a partir de projetos descentralizados e cooperativos. A Cooperativa Mista de Produção, Industrialização e Comercialização de Biocombustíveis do Brasil Ltda. (Cooperbio), vinculada ao MPA, operacionaliza a implantação de tal proposta.

O MPA, no Sistema Camponês de Produção, procura cruzar a produção de agrocombustível e cultivos alimentares a partir do território. Esse cruzamento é denominado de Alimergia. Apesar dos frágeis resultados econômicos e da semelhança da produção de agrocombustível a um pequeno agronegócio, o SCP é um ordenamento produtivo de alimentos e agroenergia erguido de baixo para cima; a partir da comunidade ou das unidades camponesas de produção.

Os biocombustíveis podem ser produzidos em modelos alternativos que integrem a produção de alimentos, energias renováveis e serviços ambientais em sistemas descentralizados organizados pela 
agricultura camponesa. Este modo de produção está focado na autonomia energética em níveis de unidade de produção, comunitária, territorial e interterritorial de forma a articular-se com os sistemas de produção de alimentos, serviços ambientais e com a ocupação popular do território, garantindo suporte econômico-ecológico sustentável a produção e reprodução de sistemas camponeses e sua relação com as cidades, integrando estes dois sistemas em um contínuo de trocas materiais, energéticas e econômicas (CAVALETT; LEAL e RYDBERG, 2010, p. 2).

Os assentamentos de reforma agrária também possuem forte expressão territorial camponesa. O assentamento é uma conquista praticamente arrancada das mãos e domínio dos latifundiários, ou seja, trata-se da territorialização dos sem-terra e desterritorialização dos proprietários latifundiários.

A realização dos assentamentos de reforma agrária geralmente é precedida pelas ocupações de terra. As ocupações e acampamentos sem-terra também possuem conteúdo territorial, pois implicam no solapamento do domínio dos latifundiários sobre um determinado espaço.

Entretanto, é necessário observar que, embora o acampamento apresente conteúdo territorial, ele é uma etapa do processo de territorialização camponesa, pois é transitório, é busca. A ocupação é um pré-requisito para a territorialização mais intensa dos sem-terra materializada nos assentamentos, ou seja, o assentamento possui uma força territorial mais intensa porque o camponês possui maior domínio sobre o espaço. Assentar na terra é dominar, controlar e ter poder sobre o espaço, o que conforma o território.

Mas o território é um espaço em disputa, pois os camponeses não exercem a dominação/controle/ poder total e completo sobre o espaço. Se os camponeses não possuem domínio total do território, o capital também não possui o monopólio completo, pois se se verificam relações de dominação e exploração, verificam-se também solidariedade, espírito comunitário, ajuda mútua, produção de subsistência. Nesse sentido, o território é um espaço em disputa em que uma classe apresenta-se hegemônica, mas não tem o domínio total.

A partir da terra conquistada se desdobram novas lutas num processo que articula acampamento-ocupação e assentamento, permitindo a espacialização das lutas e territorialização camponesa, ou seja, a partir do domínio de um pedaço de espaço as lutas se ampliam. Nesse sentido, o território, base e "chão" onde se erguem as lutas, é o centro de comando e "quartel-general" dos camponeses, ou seja, é do território que emana a força dos movimentos sociais no campo. As lutas camponesas se alimentam da força do território.

Além de permitir a espacialização das lutas, a conquista do território camponês serve para potencializar a cooperação, solidariedade e construção da igualdade entre as pessoas. Nos assentamentos são recuperados e recriados um conjunto de saberes e conhecimentos que estavam perdidos no território latifundiário e do agronegócio. Assim, os valores comunitários, solidariedade, trabalho e ajuda mútua, produção de subsistência, por exemplo, não são varridos completamente do espaço agrário.

\section{RELAÇÃO ENTRE TERRITÓRIO E MOVIMENTOS SOCIAIS}

Movimentos sociais e território são categorias que se identificam, pois ambas estão à contramão de decisões centralizadas de cúpulas estatais, partidárias ou empresariais. Tais categorias estão relacionadas a uma ordenação social construída de "baixo para cima", em que a sociedade civil organizada assume poder sobre o espaço. Portanto, possuem uma dimensão política construída a partir da base - base esta que se constitui no centro de comando na tomada das decisões.

Segundo Gohn (1997), existem diferentes paradigmas nos estudos dos movimentos sociais, dentre os quais se destaca o marxista, considerado pela autora como aquele que trouxe maiores contribuições para o entendimento da temática. A partir de diversos autores do marxismo, tais como Gramsci, Lênin, Trotsky, Rosa Luxemburgo e Mao Tse Tung, é possível escudar-se no conflito de classes e no poder revolucionário das "massas" para a transformação social. Porém, os movimentos 
sociais não devem sempre ser considerados revolucionários, objetivando rupturas sociais e quebra da hegemonia da classe capitalista, pois existem aqueles de natureza reivindicativa, ligados à cidadania e à garantia de direitos previstos na legislação.

Dentre os movimentos que realizam luta por transformações estruturais, destacam-se os movimentos sociais camponeses. Apesar da diversidade de concepções e manifestações, grande parte dos movimentos camponeses visa solapar a apropriação concentrada da terra, considerada a base da estrutura capitalista no campo e responsável pela miséria, violência, pobreza e barbáries diversas. Segundo o IBGE, considerando o censo de 2006, enquanto $0,9 \%$ dos grandes estabelecimentos detinham $44 \%$ das terras no Brasil, $47 \%$ de pequenos estabelecimentos ocupavam apenas $2,7 \%$ da área total.

Embora os movimentos sociais sejam questionadores das estruturas sociais, a organização sindical e partidária foi considerada, de acordo com o paradigma leninista, a principal representação de classes. Na sociedade moderna do período industrial, dividida entre proletariado, burguesia e proprietários de terra, com destaque para os primeiros, o partido e o sindicato seriam a forma hegemônica de organização. Nesse contexto, se fortaleceu o "movimento operário", organizado a partir do trabalho na fábrica.

Entretanto, a "reestruturação produtiva do capital", a partir de 1970, que tende à atomização e fragmentação do trabalho, fez surgir diferentes sujeitos e categorias sociais que não foram abarcados pelas estruturas homogêneas e impermeáveis do "movimento operário". Assim, diversas categorias sociais, nem sempre forjadas pelos laços profissionais e trabalhistas da fábrica, como indígenas, negros, homossexuais, sem-terra, dentre outros, começaram a se organizar nos movimentos sociais para defender seus direitos e mudanças sociais. No campo, diversos sujeitos sociais se organizaram no movimento dos posseiros, mulheres agricultoras (e, agora, camponesas), atingidos por barragem, sem-terra etc.

Existe a interpretação de que a partir de transformações produtivas, tecnológicas e na comunicação os movimentos sociais passaram a formar redes com ações políticas de alcance nacional e até mundial, como se houvesse uma "globalização", não só da mercadoria, mas também das lutas e resistências. A Via Campesina, uma organização mundial dos camponeses contra a globalização do capital, seria exemplo dessa articulação em escala mundial.

Segundo Scherer-Warren (1999), formaram-se redes de movimentos sociais, permitindo uma articulação entre local, nacional e mundial; particular e universal; uno e diverso.

A análise em termos de redes de movimentos implica buscar as formas de articulação entre o local e o global, entre o particular e o universal, entre o uno e o diverso, nas interconexões das identidades dos atores com o pluralismo (SCHERER-WARREN, 1999, p. 27).

No entendimento de Scherer-Warren (1999), a criação de rede de movimentos sociais implicou no estabelecimento de relações democráticas e abertas ao pluralismo e à diversidade cultural, em contraponto às ações políticas caracterizadas pela centralidade das decisões e hierarquização do poder. Nessa compreensão, a rede de movimentos sociais possibilitou a difusão de ideais democráticos, conectando filosofias locais ao "global", e vice-versa, em que questões do cotidiano se tornam planetárias.

Entretanto, é necessário destacar que não foi necessariamente a globalização - ou "uma outra globalização", conforme defendeu Santos (2000) - que fortaleceu a resistência dos movimentos sociais, como se houvesse uma "boa" globalização. Aliás, os movimentos sociais são movimentos antiglobalização. Assim, o território, e não necessariamente as redes, constituem-se em base fundamental de ação dos movimentos sociais camponeses.

Além da dimensão escalar, os movimentos também estão relacionados a arranjos políticos não-institucionalizados, ou seja, uma forma de fazer política em que a temática do poder continua central nas discussões, mas numa nova visão da realidade, agora constituída de novos e plurais 
espaços políticos. Os movimentos desenvolveram uma cultura política de base, autogestão, livre organização, direito à diversidade e respeito à individualidade.

Os movimentos sociais se constituem numa forma de fazer política que fortalece as decisões tomadas na base com participação de todos os sujeitos envolvidos. Grzybowski (1990), em seu estudo Caminhos e Descaminhos dos Movimentos Sociais no Campo, afirma que os trabalhadores do campo forjam-se a si mesmos e constituem-se em sujeitos com identidades sociais próprias nos movimentos sociais.

Nesta perspectiva, os trabalhadores rurais, fazendo diferentes movimentos, forjam-se a si mesmos como sujeitos diferentes, membros de grupos sociais determinados, com linguagem e identidades sociais próprias. [...] Enquanto espaços de socialização política, os movimentos sociais permitem aos trabalhadores: em primeiro lugar, o aprendizado prático de como se unir, organizar, participar, negociar e lutar; em segundo lugar, a elaboração de identidade social, a consciência de seus interesses, direitos e reivindicações; finalmente, a apreensão crítica de seu mundo, de suas práticas e representações, sociais e culturais (GRZYBOWSKI, 1990, p. 59).

Os movimentos sociais estão presentes no campo desde passado distante e não se trata de uma inauguração. Alguns autores, entretanto, abordam os movimentos na perspectiva do novo, ou seja, formas novas de fazer política, diferentes das tradicionais, como o partido e sindicato. Vigevani (1989), por exemplo, considera que são novos movimentos porque enfatizam a organização comunitária, evitam a institucionalização e permitem a participação de todos nas tomadas de decisões e na execução das tarefas e lutas.

Ainda que os movimentos impliquem numa possibilidade de participação erguida a partir das bases, ela não deve se confundir com um "basismo", em que os sujeitos encontram-se dispersos e desenvolvem uma ação política espontânea e sem forma definida. Nesse sentido, emergiu certa "institucionalização", sobretudo a partir da década de 1990, quando os movimentos sociais passaram a apresentar uma dimensão orgânica mais forte de vínculo da "base" com a "direção"; esta, saída do berço de lutas. Uma estrutura de organização se fortaleceu com a formação de secretarias regionais, estaduais, nacional e até internacional, articuladas entre si, como ocorre no MST, por exemplo.

Autores como Ricci (2009), por exemplo, entendem que os movimentos sociais surgidos na década e 1970 e 1980, como os apresentados anteriormente, possuem substanciais diferenças dos movimentos contemporâneos. Não seria possível, inclusive, entender os movimentos contemporâneos com os instrumentais teóricos da década de 1980. O autor afirma que muitos movimentos sociais que possuíam o objetivo de lutar por direitos, aumentando o poder da sociedade civil, são na realidade organizações sociais, caracterizadas pela existência de hierarquias, orçamento, formação política, equipamentos, sede administrativa etc.

Quase não existem movimentos sociais brasileiros tal como ocorreram nos anos 80 . A quase totalidade deles é, hoje, organização. Movimento Social não possui hierarquia, se caracteriza por mecanismos de democracia direta para tomada de decisões e luta por direitos, utilizando o conflito aberto como prática política. O que temos hoje são organizações populares, com a hierarquia, orçamento fixo, fontes de recursos regulares, formação política e técnica própria, equipamentos e segmento administrativo. $\mathrm{Na}$ prática, disputam entre si a obtenção de recursos. O que não significa que não mobilizam socialmente (RICCI, 2009, p. 2).

Segundo Ricci (2009), ainda, na década de 1980, os movimentos questionavam a institucionalidade. Já nos dias atuais, se incorporaram à estrutura institucional, sendo que muitas de suas lideranças estão inseridas até nos governos. Essa prática não apenas intensificou a institucionalização, mas fez avançar a estatização e ações pragmáticas e centralizadoras, trazidas das experiências sindicalistas.

Os movimentos passaram também a depender mais de recursos estatais do que de projetos coletivos de financiamentos externos, ativando o processo de estatismo da sociedade civil organizada, 
que foi perdendo sua capacidade de intervenção. Assim, o Estado se fortaleceu e a sociedade civil se enfraqueceu, pois os movimentos sociais que, no passado (década de 1970 e 1980), eram sujeitos políticos protagonistas estão se tornando objeto de políticas governamentais (ROSA, 2010, p. 1).

Nesse sentido, Ricci (2009) afirma que, resultante dessa relação com o Estado, sobretudo no governo Lula, as organizações populares perderam a sua capacidade de formulação política, pois foram engolidas pela dimensão estatal e parlamentos, desdobrando-se na energia dos movimentos. Por isso, segundo o autor, a era dos movimentos sociais calcada no ideário da participação e decisão política tomada na base, tal como surgido na década 1970, acabou. Agora a política é coisa de profissionais.

A Era dos Movimentos Sociais acabou. Ela teve início no final dos anos 70 e foi concluída logo após a constituinte de 87. Foi marcada pela hegemonia do ideário participacionista. Neste século, a hegemonia é do profissionalismo da política, a capacidade de governança, o retorno de quem fez política nos bairros e fábricas para suas casas e conversas com amigos. A política agora é coisa de quem ganha para isto (RICCI, 2009, p. 2).

Apesar das diferentes compreensões e características dos movimentos sociais, verifica-se no campo a presença de lutas "dirigidas" pelos próprios sujeitos desde passado distante. Embora tais lutas no campo fossem organizadas pelos próprios sujeitos, autores como Hobsbawm (1999) entendem que não eram movimentos essencialmente políticos, pois estavam vinculados a um microcosmo (espaço regional), fragmentado e parcial. O autor não vê possibilidade de um movimento nacional, amplo e abrangente de camponeses, sendo mais provável um movimento estimulado de fora, de cima para baixo, pois os camponeses, inseridos socialmente no contexto subalterno, não poderiam exercer política em dimensão geográfica e social ampla. Assim, o campo é interpretado por Hobsbawm (1999) como espaço habitado pela ausência da política.

Nessa compreensão, as manifestações e lutas camponesas do passado eram lutas no máximo pré-políticas e messiânicas, pois os camponeses seriam uma não-classe (ou no máximo "classe em si”, quando não há consciência de classe), refratários às manifestações coletivas. Segundo Franco (1997), o contexto em que o camponês esteve inserido no passado, no caso a ordem colonial, gerou um conformismo construído num engenhoso sistema de dominação pessoal.

As condições de sua sujeição - homem pobre do século XIX - advieram justamente por ser quase nada na sociedade e exatamente esse vazio não poderia fornecer-lhe uma referência a partir da qual se organizasse para romper as travas que o prendiam e para construir um mundo seu. Apenas episodicamente, como nos movimentos messiânicos, abriu-se para ele a possibilidade de desvendar o mundo do ponto de vista das mudanças que nele pretenderia realizar. Quando a consolidação da grande propriedade fundiária o privou dos alicerces de seu antigo estilo de vida, não foi para um esforço de organização do futuro que se canalizaram as energias do caipira: estas se sublimaram em representações nostálgicas que valorizam um passado farto seguro para o qual gostariam de poder voltar (FRANCO, 1997, p. 113).

A dificuldade dos camponeses de se situar politicamente estaria relacionada à sua inserção na sociedade de classes, pois não era um operário (proletário) nem um capitalista (burguesia). Numa sociedade de classes dividida entre "escravo e senhor", ou "operário e burguesia", não havia lugar social para o campesinato e a possibilidade de projeção da sua luta. Assim, os camponeses, em vista de sua condição de classe, foram entendidos como se não tivessem projeto de totalidade. Seu projeto e luta eram pela busca de benefícios individuais e imediatos, semelhante à cômica resistência camponesa de Pedro Malasartes.

Embora entendidas pelo pensamento marxista ortodoxo como parte de um projeto individual e pequeno-burguês, as lutas camponesas pela terra nos movimentos sociais foram protagonistas de importantes manifestações coletivas, como a campanha de Canudos, as Ligas Camponesas, dentre 
outras. Essas lutas, inclusive, guardadas as suas diferenças, se projetam nos dias atuais. Mas, se os movimentos camponeses no passado eram guiados pela busca da terra, nos dias atuais, os movimentos lutam pela reforma agrária, ou seja, uma reivindicação mais ampla do que a terra.

A luta pela reforma agrária possui um sentido mais amplo porque está inserida, sobretudo, num projeto de nação, ou seja, a reforma agrária é necessária não somente para os camponeses, mas para o desenvolvimento da nação brasileira: para todos. O MST inclusive defende que a "reforma agrária deve ser uma luta de todos", pois toda a sociedade, e não somente o sem-terra, se beneficiaria dela.

Nesse contexto de luta pela reforma agrária, emergiu o discurso desenvolvimentista, apropriado e reconstruído pelos movimentos sociais, pois a eficiência produtiva camponesa teria papel importante no desenvolvimento da nação. Assim, os camponeses possuem lugar social definido a partir de uma pauta econômica, ou seja, seu lugar social estaria garantido por sua eficiência produtiva de alimentos, por exemplo.

A partir da capacidade produtiva da pequena agricultura, a dimensão econômica se fortaleceu no discurso dos movimentos sociais. Martins (1994) afirma que houve uma alteração de prioridades na ação do que considera "mediadores" da reforma agrária na "nova república", quando a figura do posseiro foi substituída pela figura do sem-terra, deslocando o eixo central da questão da terra. A luta dos posseiros estava respaldada por um forte conteúdo moral, pois o grileiro era sinônimo de delinquente, criminoso e violento. Já a luta dos sem-terra não se dá com base no mesmo argumento moral, mas no argumento econômico.

Os sem-terra foram forçados a desenvolver sua luta num terreno desfavorável - o terreno do adversário. Isso porque a ocupação de terra não se deu com base no mesmo argumento moral da precedência do posseiro, com seu trabalho, em relação ao grileiro, mero especulador fundiário. Mas se deu com base no argumento econômico da propriedade improdutiva (MARTINS, 1994, p. 151).

A eficiência produtiva camponesa, necessária para o desenvolvimento do Brasil, é verificada a partir do cotejamento de dados da área cultivada, financiamentos de investimento e custeio às lavouras e produção dos pequenos agricultores (aqueles detentores de menos de quatro módulos fiscais). Esses pequenos agricultores, dispondo de apenas $24,3 \%$ da área total de terras do país (IBGE, 2006) e poucos recursos financeiros (16 bilhões, de acordo com o plano safra 2010-2011), são responsáveis por $100 \%$ da produção de verduras, $87 \%$ da de mandioca; $70 \%$ do feijão; $59 \%$ dos suínos, $58 \%$ de leite; $50 \%$ das aves, $46 \%$ do milho; $38 \%$ do café etc. Acrescenta-se ainda que, enquanto as pequenas propriedades empregam $74,4 \%$ dos trabalhadores e ocupam 15 pessoas a cada 100 hectares, a agricultura de negócio (agronegócio) emprega apenas 25,6\% do trabalhadores e ocupa somente 1,7 pessoa. Essa diferença ocorre porque o agronegócio utiliza muita tecnologia poupadora de mão-de-obra, dentre outros motivos.

A partir da perspectiva de hegemonia da dimensão econômica, o Estado, representado pelo MDA, os movimentos sociais de luta pela reforma agrária, bem como intelectuais comprometidos com essa luta entendem a agricultura camponesa e seu território como indutores do desenvolvimento. Nessa concepção, o território se constituiria num trunfo para potencializar a capacidade produtiva, caminho para o empoderamento dos camponeses, como destacado anteriormente.

Apesar da comprovada eficiência produtiva e sua relação com o desenvolvimento, a eficiência política dos camponeses é pequena se comparada com a dos ruralistas. A eficiência política dos latifundiários e agronegociantes pode ser verificada na formação de uma bancada ruralista no Congresso Nacional, responsável por lobbies diversos para perdão e rolagem de dívidas, alocação de recursos financeiros, proteção a infratores da legislação ambiental e trabalhista etc.

Embora desproporcionalmente menor, não é desprezível a versatilidade dos movimentos sociais, que, em função das suas conquistas, como a terra de assentamento, por exemplo, tornaram-se paradigmáticos nas resistências e lutas no campo. Assim, emergiu o protagonismo das lutas pelos movimentos sociais construídos como centrais nas resistências camponesas. 
A centralidade dos movimentos sociais é verificada inclusive no fato de serem educativos, pois no processo de luta os sujeitos aprendem a identificar o seu opressor. A participação nos movimentos sociais permite que pessoas adormecidas para a vida política possam para ela despertar. É como dizem os próprios sujeitos da luta: "no movimento, o camarada abre o olho e enxerga certas coisas".

A participação nos movimentos sociais permite ao sujeito enxergar a sua condição de oprimido e "excluído" da apropriação dos meios de produção, principalmente a terra. A partir da consciência política, se mobilizam e lutam, não somente para garantir o seu direito e cidadania, mas também por transformações sociais advindas da igualdade na distribuição da terra. Enfim, a partir dos movimentos sociais os sujeitos do campo se emancipam social, política e economicamente.

Mas, paradoxalmente, observa-se que o discurso da emancipação a partir da transferência de poder à sociedade civil organizada pode se comunicar também com o ideário liberal (ou neoliberal) de menor participação do Estado na solução dos problemas sociais. A sociedade civil organizada decide e resolve ela mesma os seus problemas, gerando uma desobrigação do Estado. Assim, por exemplo, a falta de uma escola rural ou via para escoamento de produção agrícola num assentamento seria um problema resolvido pela própria comunidade, sem depender do Estado (município, estado ou União).

Essa "transferência" de poder aos sujeitos, inclusive, é defendida pelos segmentos dominantes da sociedade. A compreensão de autodeterminação dos sujeitos vinculada ao território e à sociedade civil organizada é aceitável por governos, empresários, teóricos e segmentos multilaterais como o Fundo Monetário Internacional e o Banco Mundial. Safatle (2010) afirma que essa concepção coaduna também com posturas partidárias liberais, tal como a dos Verdes na eleição de 2010, por exemplo, desejosos de postura "moderna" e menos centrada no conflito de classes, distribuição de renda, subordinação, precarização do trabalho etc.

Não é de se estranhar que este libertarianismo encontre, 40 anos depois, o liberalismo puro e duro. De fato, a ocupação do centro pelos verdes tem tudo para ficar. Ela vem a calhar para um eleitorado que um dia votou na esquerda, mas que gostaria de um discurso mais "moderno". Um discurso menos centrado em conflitos de classe, problemas de redistribuição, precarização do trabalho e mais centrado em "nova aliança", "visão integrada" e outros termos que parecem saídos de um manual de administrador de empresas zen (SAFATLE, 2010, p. 2).

Entretanto, apontar os limites da sociedade civil organizada e do território enquanto instância de decisão política não significa absolutizar o poder estatal. As decisões estatais devem ser colocadas a serviço dos movimentos sociais e da sociedade civil organizada e, portanto, não se trata de desobrigação, semelhante ao ideário neoliberal.

\section{EXPRESSÃO TERRITORIAL DAS CONTRADIÇÕES SOCIAIS NO CAMPO}

Considerando a formação territorial a partir das relações de poder e controle sobre o espaço, é possível verificar o conflito entre a territorialização das relações capitalistas no campo, expressa no agronegócio e latifúndio, e a territorialização camponesa. Nesse contexto de conflito entre agronegócio, latifúndio e campesinato, pode ocorrer a afirmação ou negação do território derivadas de diferentes enfrentamentos e conflitos sociais.

Os conflitos sociais entre as classes são uma característica da construção territorial do espaço agrário brasileiro. Esses conflitos territoriais no campo brasileiro vêm desde passado distante, quando se iniciou a colonização e exploração de produtos tropicais que interessavam ao mercado internacional europeu no século XVI. A exploração agrícola colonial e o monopólio da posse da terra pelos setores proprietários dominantes indicavam a formação do território latifundiário colonial.

A posse da terra era regulada pela Lei das Sesmarias e somente uns poucos, aqueles possuidores de escravos, detinham o seu domínio, formado por grandes lavouras de cana-de-açúcar. O poder do 
senhor era derivado não diretamente da propriedade da terra, mas da posse de escravos. Portanto, a posse de escravo permitia a uma oligarquia dominar a terra.

Aqueles agricultores que não possuíam escravos serviam de instrumento de senhores para desbravar as terras com a produção de gêneros de subsistência e um pequeno excedente comercializado nas cidades. Os pequenos agricultores desenvolviam atividades agrícolas separadas, mas complementares à grande lavoura, trabalhando na maioria das vezes com a própria família. Essa foi a origem da pequena agricultura no Brasil.

Após o fim do sistema de Sesmaria, no início do século XIX, ocorreu aumento das posses, até que, em 1850, foi aprovada uma nova lei (Lei de Terras) definindo que a apropriação da terra deveria se dar mediante a compra. Como destacou Martins (1977), instalou-se o "cativeiro da terra”, desdobrando-se na intensificação da concentração de terras e domínio do espaço agrário pelos grandes proprietários.

A partir da década de 1950 ocorreu maior integração econômica nacional. As regiões Nordeste, e principalmente a Amazônica, foram incorporadas à dinâmica nacional, o que aumentou ainda mais concentração de terras no Brasil. Acrescente-se a esse processo as mudanças ocorridas com a modernização da agricultura brasileira a partir de 1970, quando muitos pequenos estabelecimentos acabaram sendo absorvidos pelos médios e grandes proprietários, levando à expropriação e expulsão de camponeses.

No contexto de modernização da agricultura houve o fortalecimento dos complexos agroindustriais (CAI) e algumas propriedades latifundiárias se transformaram em empresas rurais de agronegócio. $\mathrm{O}$ agronegócio é um sistema que compreende a associação entre agricultura, indústria e finanças, e que, patrocinado pelo Estado, visa ampliar a obtenção de lucro e renda. Assim, verificou-se a materialização de típicas relações capitalistas a partir da produção de mercadorias em substituição ao latifúndio atrasado, expressão de "irracionalidade" capitalista (não-capitalista).

O discurso positivo aponta para a importância econômica do agronegócio, uma vez que seria responsável pela elevação da produção agrícola, geração de emprego, superávits da balança comercial etc. Os benefícios econômicos se traduziriam, segundo essa compreensão, em benefícios sociais, e, de "vilões" que eram no passado, os grandes proprietários rurais tornaram-se "heróis" da nação. Assim, seria possível verificar que as propriedades rurais latifundiárias, antes responsáveis pela miséria e pobreza porque não produziam, se transformaram em verdadeiras empresas rurais, ou seja, imóveis altamente produtivos, explorados racionalmente e responsáveis por vários benefícios econômicos e sociais.

Entretanto, numa compreensão crítica e mais adequada à realidade, verifica-se que o agronegócio é responsável pela geração da pobreza, miséria, exploração, opressão etc. O agronegócio tornou-se, no entendimento de muitos autores como Canuto (2004), por exemplo, sinônimo de produtividade, mas uma produtividade excludente, promotora da pobreza, miséria, degradação ambiental, violências e tantas outras mazelas e barbáries. Partindo desse pressuposto, ainda, Fernandes (2010) entende que o agronegócio se fortaleceu e os latifúndios improdutivos estão deixando de jogar papel importante no campo brasileiro.

Na compreensão desses estudiosos do campo brasileiro, bem como de movimentos sociais, como o MST, o latifúndio excluía pela não-produção e agora o agronegócio exclui pela produção, sendo considerado o principal inimigo dos movimentos sociais camponeses e da reforma agrária.

A partir do início da década de 1990, a questão agrária constituiu-se de novos elementos. O latifúndio deixou de ser o principal problema para o desenvolvimento da agricultura camponesa. $O$ desafio maior para a implementação da reforma agrária passou a ser o agronegócio, com toda sua potencialidade. Para combater as lutas por terra, os defensores do agronegócio criaram uma política de "reforma agrária de mercado" (FERNANDES, 2010, p. 187).

Essa compreensão de que o agronegócio implica na exclusão pela produção, diferentemente do latifúndio, que excluía pela não-produção, comunica-se com a tese de que o capitalismo se expande 
no campo pela produção capitalista de mercadorias. O fator terra (renda fundiária) não se constituiria mais no núcleo central da acumulação, mas sim os fatores trabalho e capital. A acumulação rentista, caracterizada pela não produção agrícola, em tese, ficaria em plano secundário, pois será o capital produtivo que caracterizará a questão agrária. Assim, a questão agrária brasileira estaria mais centrada na produção agrícola do que na especulação da terra improdutiva.

Entretanto, é necessário considerar que a expansão do modo capitalista de produção é contraditória e desigual, uma vez que cria/recria relações não-capitalistas. Oliveira (2003) afirma que o agronegócio, uma face moderna da agricultura capitalista brasileira, esconde o "velho" caráter especulativo da agricultura capitalista (rentismo), de produção para a exportação, de concentração da terra e superexploração da força de trabalho, como é o caso das condições de trabalho análogo à escravidão de cortadores de cana.

Segundo Delgado (2010), no período neoliberal de FHC, quando houve expansão forte do agronegócio, a renda da terra passou por diferentes arranjos e acomodações e a expansão do agronegócio foi acompanhada da presença de amplas áreas improdutivas, indicando uma acumulação "típica" do capital rentista.

A área produtiva incorporada pela expansão do agronegócio é desproporcionalmente pequena em comparação com ao território "improdutivo" controlado pelo sistema, sobretudo nas regiões de fronteira econômica ou de incorporação recente. Essa terceira restrição, ou condição da expansão constrangida, reflete uma típica associação da acumulação produtiva com a acumulação fundiária. Ela é peça essencial na estratégia simultânea de captura da renda agrícola e da renda fundiária pelos proprietários de territórios “improdutivos", contíguos aos espaços da efetiva produção (DELGADO, 2010, p. 97).

Diante desse contexto, os camponeses organizados nos movimentos sociais, como destacado anteriormente, resistem bravamente ao projeto de desenvolvimento das oligarquias e empresários rurais, indicando que os conflitos sociais são também conflitos territoriais: o território do agronegócio e latifúndio em contraposição ao território camponês. Acrescenta-se que o território camponês é portador de um conjunto de práticas não-capitalistas, como produção de autoconsumo e resistência, controle relativo do processo produtivo, autonomia, relações comunitárias e solidárias, dentre outras.

A existência e recriação do campesinato estão relacionadas também à realização da reforma agrária, bandeira de luta dos movimentos camponeses. A reforma agrária é exemplo de expansão do território camponês e recuo do território latifundiário e do agronegócio, o que permite comparar/ confrontar esses dois projetos.

A partir desse confronto pelo domínio do espaço entre camponeses e agronegócio/latifundiário, é possível conceber o território como expressão das contradições sociais. Se, de um lado, o território se constitui numa expressão e trunfo para as relações capitalistas, como destacado anteriormente, de outro, serve à resistência dos camponeses nos movimentos sociais. Por isso, há que se abordar e compreender o território como uma construção social sujeita aos interesses de classes, como dos latifundiários e camponeses, por exemplo.

É nesse sentido contraditório, de resistência e subordinação, que deve ser interpretado o território. Trata-se de uma contradição territorial derivada das classes sociais, consideradas protagonistas na formação do território, pois é a partir da sociedade de classes que se forma o território.

\section{CONSIDERAÇÕES FINAIS}

A partir dos apontamentos sobre território e movimentos sociais no campo é possível chegar a um conjunto de constatações. Verifica-se que território se constitui numa categoria de importância fundamental para interpretar a força dos movimentos sociais, pois é dele que se erguem as lutas sociais. A dimensão territorial e a organização dos sujeitos (os camponeses) nos movimentos sociais implicam em tomada de decisões a partir das bases e não de cúpulas estatais, partidárias, corporativo-empresariais etc. 
Entretanto, há a interpretação de território como um potencializador da produção de mercadorias de base local. É nesse sentido que os segmentos dominantes expressos nos governos, empresas, órgãos multilaterais, alguns estudiosos, dentre outros, aprovam a dimensão territorial: uma dimensão territorial capaz de potencializar a produção de mercadorias e o desenvolvimento local.

Contudo, o território pode ser interpretado como um trunfo para negar os esquemas de produção de mercadoria e relações competitivas, potencializando as forças sociais de resistência. Por isso, a compreensão do território deve ser feita a partir dos diferentes interesses, conflitos e contraditórios expressos na dimensão de classes, uma vez que é a partir da sociedade de classes que se forma o território e não necessariamente deste que se formam as classes.

Eis, pois, o sentido da relação entre território, classe e movimentos sociais no campo.

\section{REFERÊNCIAS BIBLIOGRÁFICAS}

ABRAMOVAY, R. O capital social dos territórios: repensando o desenvolvimento rural. Seminário de Reforma Agrária e Desenvolvimento Sustentável. Fortaleza: Digitado, p. 8, 1998.

BRANDÃO, C. A. Territórios, classes sociais, conflitos, decisão e poder. In: ORTEGA, A. C.; ALMEIDA FILHO, N. Desenvolvimento territorial, segurança alimentar e econômica solidária. Campinas: Alínea, 2007.

CANUTO, A. Agronegócio: modernização conservadora que gera exclusão pela produtividade. Revista Nera, Presidente Prudente, n. 5, ano 7, ago./dez. 2004.

CARREIRA, F.; FRANCO, A. Redes melhoram ambiente em que vivemos. Folha de Londrina, Londrina, 22 dez. 2010. Opinião, p. 03.

CAVALETT, O.; LEAL, M.; RYDBERG, T. Avaliação emergética de sistema camponês de produção de álcool, alimentos e serviços ambientais. In: LEAL, M. 2010. No prelo.

DELGADO, G. D. A questão agrária e o agronegócio no Brasil. In: CARTER, M. (Org.) Combatendo a desigualdade social. São Paulo: Editora Unesp; CBS-University of Oxford; Nead, 2010.

FERNANDES, B. M. Formação e territorialização do MST no Brasil. In: CARTER, M. (Org.) Combatendo a desigualdade social. São Paulo: Editora Unesp; CBS-University of Oxford; Nead, 2010.

FRANCO, M. S. C. Homens livres na ordem escravocrata. São Paulo: Editora da Unesp, 1997.

GOHN, M. G. A Abordagem marxista nos estudos sobre os movimentos sociais. Anais do I Colóquio Marx Engels. Campinas: Cemarx, 1999, n. 1. p. 1-10.

GRZYBOWSKI, Cândido. Caminhos e descaminhos dos movimentos sociais no campo. Petrópolis: Vozes, 1990.

HAESBAERT, R. O Mito da desterritorialização. Rio de Janeiro: Bertrand Brasil, 2004.

HOBSBAWM, E. Pessoas extraordinárias: resistências, rebelião e jazz. 2 ed. São Paulo: Paz e Terra, 1999.

MAIA, L. O conceito de território e o fetichismo do poder. Ateliê Geográfico, Goiânia, v. 4, n. 10 abr. 2010. p. $169-189$.

MARCOS, V. e FABRINI, J.E. Os camponeses e a práxis da produção coletiva. São Paulo: Expressão Popular. 2010.

MARTINS, J. S. O Cativeiro da Terra. São Paulo: Paz e Terra, 1986

MARTINS, J. S. O Poder do atraso. São Paulo: Hucitec, 1994.

MDA. Referências para o desenvolvimento territorial sustentável. Brasília: NEAD, 2003. Série texto para discussão, n. 4.

MPA. Possibilidades para o campesinato na produção de alimento e energia. Frederico W. Seminário Nacional de Reestruturação das Comunidades Camponesas. 2008.

ORTEGA, A. C. Territórios deprimidos. Campinas; Uberlândia: Alínea; Edufu, 2008.

OLIVEIRA, A. U. A geografia e os movimentos sociais. São Paulo: USP (digitado), 2007. 
OLIVEIRA, A. U. Barbárie e modernidade: as transformações no campo e o agronegócio no Brasil. Revista Terra Livre, São Paulo, ano 19, v. 21, n. 21, jul./dez. 2003. p. 113-156.

RAFFESTIN, C. Por uma Geografia do Poder. Ática: São Paulo, 1993.

RICCI, R. Com o fim da era dos movimentos sociais foi-se a energia moral da ousadia. Entrevistas 30/11/2009. Disponível em <www.ihu.unisinos.br>. Acesso em: 05 nov. 2010.

ROSA, P. C. Movimentos sociais e religiosos hoje são objetos da política. Carta Capital, São Paulo, 12 nov. 2010.

SAFATLE, V. Marina Silva em Wall Street. Folha de São Paulo, São Paulo, 04 out. 2010. A-2.

SANTOS, M. Por uma outra globalização. 2a. ed. São Paulo: Record, 2000.

SAQUET, M. A. Abordagens e concepções de território. São Paulo: Expressão Popular, 2007.

SCHERER-WARREN, I. Cidadania sem fronteiras. São Paulo: Hucitec, 1999.

SILVA, J. G. O Novo rural brasileiro. Nova Economia, Belo Horizonte, v. 1, n.7, maio 1997. p. 43-81

SOUZA, M.L. O território: sobre espaço e poder, autonomia e desenvolvimento. In: CASTRO I.E. GOMES, P.C.C. CORREA, R.L. Geografia: conceitos e temas. Rio de Janeiro: Bertrand, 1995.

VEIGA, J. E. A história não os absolverá, nem a geografia. Campinas: Armazém do Ipê, 2005.

VIGEVANI, T. Movimentos sociais na transição brasileira: a dificuldade de elaboração do projeto. Lua Nova, São Paulo, n.17, 1989. p. 93-109.

Trabalho enviado em abril de 2011 Trabalho aceito em junho de 2011 